\title{
Výzkum interakce mezi spolužáky: přehled konverzačněanalytických studií1
}

\author{
František Tůma, Linda Nepivodová, \\ Nicola Fořtová
}

Masarykova univerzita, Filozofická fakulta

\begin{abstract}
Abstrakt: Interakce mezi spolužáky (např. během práce ve dvojicích nebo ve skupinách) představuje $v$ českých pedagogických vědách jednu z dosud málo probádaných oblastí. $\checkmark$ této přehledové studii proto představujeme konverzační analýzu, která poskytuje teoretický a metodologický rámec pro zkoumání probíhající interakce, a poté na základě 28 zahraničních konverzačněanalytických studií vybraných z databáze Scopus podáváme přehled o stavu zahraničního výzkumu v oblasti interakce mezi spolužáky. I když se většina studií zabývá výukou cizích jazyků a pochází z vysokého školství, existují také studie z nižších stupňů vzdělávání a z jiných vyučovacích předmětů. Studie ukazují, jak spolužáci plánují a řeší zadané úlohy, jak během takové interakce dochází k učení se (včetně osvojování cizího jazyka a rozvoje interakční kompetence u žáků a studentů), jak vrstevníci jeden druhého vyučují a jak spolužáci v interakci používají tělesné, jazykové nebo materiální prostředky. Ze studií vyplývá, že interakce typicky probíhá nelineárně a dynamicky. Tato zaměření výzkumu v závěru konfrontujeme s některými pedagogickými a psychologickými pohledy na výuku a diskutujeme o vztahu konverzační analýzy a pedagogického výzkumu.
\end{abstract}

Kličová slova: interakce mezi spolužáky, interakce ve třídě, konverzační analýza, pedagogický výzkum

\section{Research on Interaction Among Peers: A Review of Conversation-Analytic Studies of Classroom Interaction}

Abstract: Interaction among peers (e.g. within pairwork or groupwork) represents an under-researched area in Czech educational sciences. Therefore, in this article we introduce conversation analysis, which provides a theoretical and methodological framework for investigating ongoing interaction. A review of research on peer interaction published internationally in 28 conversation-analytic studies that were selected from the Scopus database is then presented. Although the majority of the studies are related to higher education and to foreign language teaching and learning, some studies were conducted at lower levels of education and in other subjects. The studies show how peers plan and solve tasks, how they learn in interaction (including foreign language acquisition and development of interactional competence), how they teach each other and how they use embodied, language or material resources. It follows that interaction is typically non-linear and dynamic in nature. We contrast these foci with some educational and psychological perspectives on learning and teaching and then discuss the relationship between conversation analysis and educational research.

Keywords: peer interaction, classroom interaction, conversation analysis, educational research

1 Článek vznikl při řešení výzkumného projektu „Interakce ve frontální výuce a skupinové práci $\checkmark$ hodinách angličtiny na střední škole“ (18-02363S). Děkujeme Grantové agentuře Ceské republiky za poskytnutou podporu. 
8 Řada autorů publikujících v pedagogickém výzkumu poukazuje na provázanost interakčních procesů s procesy učení se, čímž podtrhují důležitost interakce ve výuce a opodstatňují výzkumné snahy o popis a hlubší pochopení toho, jak interakce ve tř́dě probíhá, jakých může nabývat podob a jak v těchto spletitých interakčních procesech učitelé vyučují, jak žáci a studenti interpretují probíhající interakci a jak se v ní učí (k přehledu různých př́stupů a pojetí viz např. Markee, 2015; Waring, 2015, s. 14-44). Interakce ve výuce může probíhat $v$ řadě různých uspořádání, z nichž se české empirické výzkumy zaměřují převážně na frontální výuku (z monografií kupř. Betáková, 2010; Najvar et al., 2011; Šed’ová et al., 2016; Šed’ová, Švaříček, \& Šalamounová, 2012; Tůma, 2017a). Vedle frontální výuky však vzdělávání zahrnuje i řadu dalších uspořádání, v nichž (zatím) zůstává v českém prostředí interakce spiše neprobádána. Z nich lze jmenovat třeba komunikaci v on-line prostředí (např. Černá, 2005; Poláček, 2015), přednes studentských referátů a následné diskuse k nim (Tůma, 2017a, s. 129-152), soukromé doučování (Št’astný, 2016), dění o přestávkách (Smetáčková, Novotná, \& Šimečková, 2014) nebo právě interakci mezi spolužáky během výuky, které výzkumy provedené v Česku nevěnovaly zatím př́liš pozornosti.

Z hlediska výzkumu komunikace a vztahů mezi vrstevníky je nutné zmínit studie, které metodologicky staví na dotazníkovém šetření (např. Mareš, 2003), zaměření těchto studií nicméně stojí mimo samotný průběh interakce. Dále je možné uvést etnografii (kupř. Jarkovská, 2013; Obrovská, 2018; Pražská skupina školní etnografie, 2002), pro kterou je předmětem zkoumání společnost, kultura a související sociální kategorie. Ve vztahu k interakci mezi spolužáky musíme zmínit také kooperativní učení, které v Česku rozpracovává zejména Kasíková, nicméně rozsáhlejší empirické výzkumy zatím nejsou k dispozici (Kasíková, 2017, s. 116).

Ačkoli v minulém století byla i v českém pedagogickém výzkumu interakce mezi spolužáky zkoumána (např. Kratochvíl, 1987; Nečesaná, 1972), nejsme si vědomi žádné současné v Česku publikované analýzy průběhu interakce mezi spolužáky během práce ve skupinách nebo ve dvojicích (výjimku tvoři diplomová práce Králové, 2017). $V$ této přehledové studii proto představujeme zahraniční konverzačněanalytické studie, které detailně rozebírají interakci mezi spolužáky během výuky, abychom poukázali na metodologické aspekty a tematická zaměření takových výzkumů. Vycházíme z předpokladu, že představení konverzační analýzy jako teoreticko-metodologického rámce pro výzkum interakce mezi spolužáky a relevantních zahraničních výzkumů může přispět $\mathrm{k}$ hlubšímu poznání interakčních procesů a procesů učení se, a tedy $\vee$ důsledku $i$ teoreticky, metodologicky a empiricky vyplnit mezeru $v$ českém pedagogickém výzkumu.

$\checkmark$ této studii se zaměřme na interakci mezi spolužáky, která typicky probíhá $\checkmark$ párové nebo skupinové práci. $V$ tradiční středoevropské a německé pedagogické a didaktické tradici tato uspořádání představují organizační formy výuky a je o nich pojednáváno především z pohledu diferenciace, individualizace a integrace (např. Arnold, Sandfuchs, \& Wiechmann, 2009, s. 261-290; srov. Maňák, 2003; Václavík, 2002). V tomto textu se přikláníme spiše $\mathrm{k}$ anglosaské koncepci, konkrétně 
k tzv. edukační lingvistice (Spolsky \& Hult, 2008; ke vztahu oborové didaktiky a edu-

kační lingvistiky srov. Tůma, 2017a, s. 17-22), ve které je pro badatele ústřední jazyk a jeho role ve vzdělávání. $V$ této studii nás tedy zajímá interakce probíhající mezi žáky nebo studenty, kterou výzkumníci podrobně analyzují na základě pořízených nahrávek. Teoreticky a metodologicky přitom vycházíme z konverzační analýzy, kterou představíme v následujícím oddílu.

\section{Konverzační analýza ve výzkumu interakce mezi spolužáky}

Konverzační analýza, která se vyvinula z etnometodologie (Garfinkel, 1967), představuje teoreticko-metodologický rámec pro zkoumání přirozeně probíhající interakce. V této studii navazujeme na řadu česky publikovaných textů o konverzační analýze (např. Auer, 2014, s. 129-139; Nekvapil, 2017; Tůma, 2016) a na několik existujících studií z českého prostředí českých škol (především z frontální výuky), které z konverzační analýzy vycházejí (kupř. Češková, v rec. řízení; Janík, 2017; Majcík, 2018; Tůma, 2017a, 2017b). Zaměříme se zde proto především na specifické aspekty konverzačněanalytického výzkumu interakce mezi spolužáky.

Ústřední předpoklady konverzační analýzy, že v interakci existuje „řád v každém ohledu“ (Sacks, 1984, s. 21-22) a že mluvčí produkují interakci jeden pro druhého systematicky (Schegloff \& Sacks, 1973, s. 290), znamenají, že při analýze není možné předem vyřadit žádný aspekt interakce, protože každý detail může být pro mluvčí zásadní. To mimo jiné znamená, že v konverzačněanalytickém výzkumu se uplatňují podrobné transkripty, jejichž role je dvojí: jednak umožňují výzkumníkovi během analýzy zaznamenávat, rozebírat a usouvztažňovat jednotlivé aspekty na nahrávce zachycené interakce, a jednak umožňují čtenáři studie analyzovat publikovaný transkript.

Níže uvádíme příklad transkriptu, na kterém ukážeme některá specifika konverzačněanalytického výzkumu. Mluvčí (pseudonymy Táňa a Soňa) jsou žákyně gymnázia a v zaznamenané sekvenci z hodiny angličtiny pracují ve dvojici. Zadání úkolu znělo zodpovědět otázky z učebnice. Transkript zachycuje začátek aktivity, ve kterém mluvčí přečtou otázku z učebnice (Do you know anybody who is a bit tight-fisted?), která byla součástí lekce o penězích. ${ }^{2}$

2 Nahrávku jsme pořídili při řešení výzkumného projektu, ze kterého vznikl tento text. Transkript vychází z konvencí standardně používaných pro zachycování detailů v interakci (např. Mondada, 2011): odráží jednak jazykovou složku interakce (repliky jsou označené počátečními písmeny pseudonymů mluvčích Tá a So s velkými písmeny), jednak tělesné prostředky (zejména pohledy a pohyby, tyto jsou uvedeny na rádcích s pseudonymy mluvčích s malými písmeny; tyto prostředky jsou propojeny s replikou výše pomocí symbolů + pro Táňu a • pro Soňu). Seznam použitých značek uvádíme $v$ př́loze. Pro přehlednost transkriptu neuvádíme české překlady jednotlivých replik $v$ angličtině; průběh a obsah interakce komentujeme a analyzujeme dále v textu. 


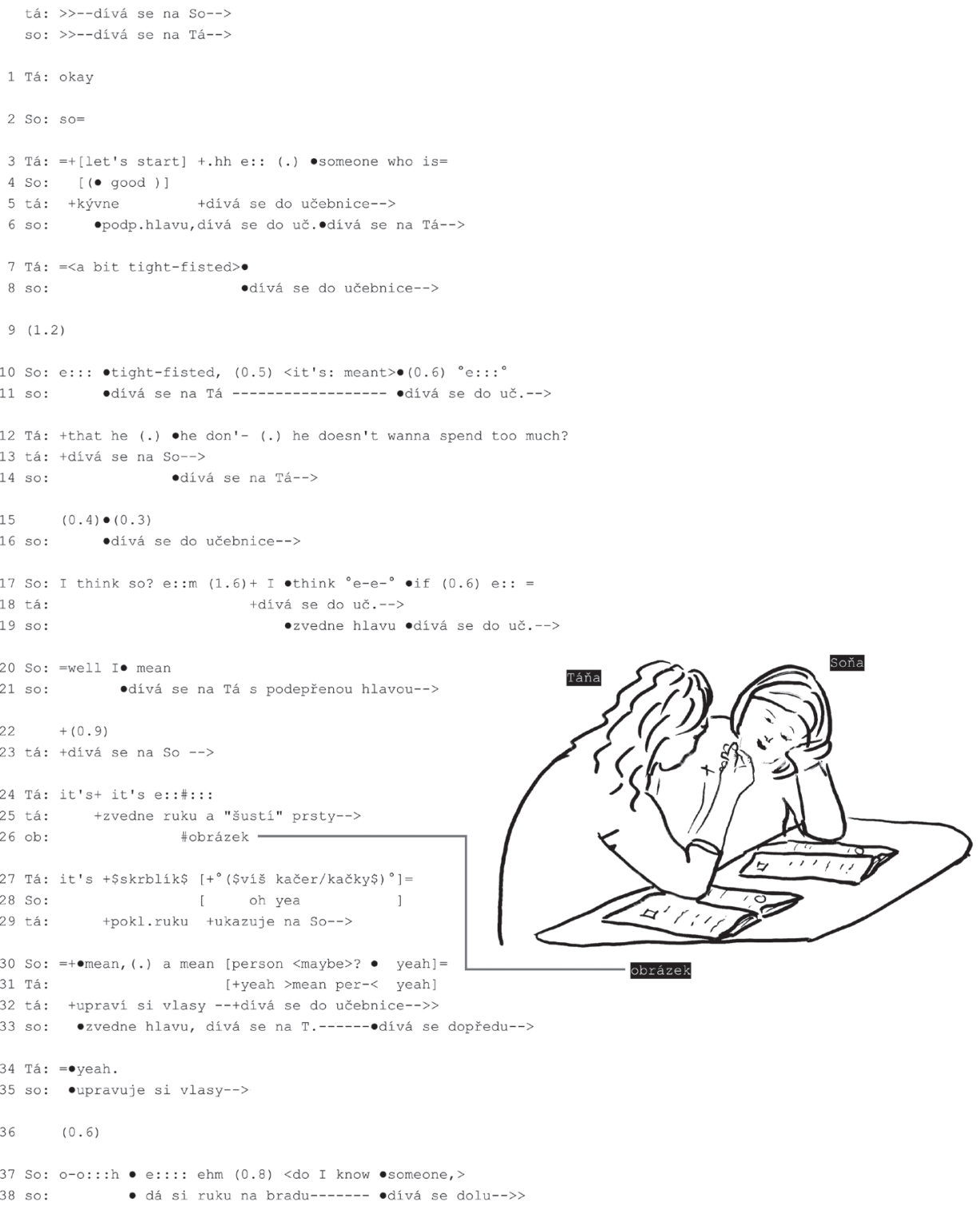

Z ukázky 1 je zřejmé, že vedle jazykových prostředků převážně z angličtiny, ale také z češtiny (řádek 27), mluvčí během interakce mění pohledy a držení těla, gestikulují nebo si upravují vlasy. Kromě toho čtou část otázky z učebnice (řádky 3 a 7) a do učebnice opakovaně nahližejí. Uvedené dokládá, že důležitou roli při interakci mezi spolužáky hrají kromě jazykových prostředků také prostředky tělesné (pohledy, 
pohyby rukou apod.) a materiální (např. učebnice), jejichž použití mluvčími v inter-

akci je v konverzační analýze důležité zaznamenat a analyzovat (Streeck, Goodwin, \& LeBaron, 2011). Na druhou stranu je prakticky nemožné zachytit interakci v celé její složitosti, protože každé záznamové zařizení zabírá pouze určitý výsek toho, co se mezi mluvčími odehrává. To je patrné z obrázku v transkriptu, který zachycuje záběr kamery. Takový záběr je pro účely analýzy interpersonální interakce mezi spolužáky postačující, nicméně pokud by bylo předmětem například to, jak žáci nebo studenti společně produkují text, bylo by nezbytné zachytit i to, co jim probíhá „pod rukama“ (kupř. umístěním kamery), podobně v případě, že žáci nebo studenti používají obrazovku (mobilu, tabletu, počítače), mưže být žádoucí zachytit obsah obrazovky (srov. Kunitz \& Markee, 2017). Kimura, Malabarbaová a Hallová (2018, s. 13) proto doporučují pořizovat nahrávku tak, aby byla dostatečným záznamem toho, co se stalo, s ohledem na zaměření výzkumu. V přehledu (oddíl 3) ukazujeme, že se typicky jedná o videozáznamy, někdy doplněné o audiozáznamy (např. použití diktafonů nebo mikrofonů).

Po pořizení záznamů výzkumník podrobně přepisuje a analyzuje interakci probíhající na záznamech (k podrobnostem a specifikům analýzy interakce ve třídě viz Tůma, 2017a, s. 31-56). Důležité je, že výzkumník při analýze vychází z dat: podle charakteru pořizených záznamů a zachycené interakce zaměří analýzu na ty aspekty interakce, které mluvčí na záznamech používají. Ukázku 1 tedy lze analyzovat následovně: Soňa použitím hezitačních zvuků, pauz a výpovědi tight-fisted, it's meant (řádek 10) pozorovatelně problematizuje význam anglického slova tight-fisted, které se nachází v učebnici a jež je předmětem otázky, kterou jí Táňa předtím položila (řádky 3 a 7). ${ }^{3}$ Tuto interpretaci Táňa svým následným jednáním potvrzuje: navazuje se Soňou oční kontakt (řádky 13 a 14) a opisem vysvětluje význam problematizovaného slova (řádek 12). Soňa pronesením I think so?, zdá se, akceptuje Tánino vysvětlení, nicméně následně neprodukuje odpověd' na položenou otázku, místo toho doplňuje řadu hezitačních zvuků, pauz a nedokončených větných konstrukcí (řádky 17 a 20). Následuje 0,9 sekundy dlouhá pauza (řádek 22), během které je zřejmé, že se obě studentky navzájem vnímají (navázaly oční kontakt), nicméně Soňa stále neprodukuje odpověd' na otázku, což Táňa vyřeší tím, že nabídne možný český překlad dřive problematizovaného slova (skrblík, ráádek 27) doplněný gestem znázorňujícím „šustění“ penězi (viz obrázek v ukázce, řádek 26). Soňa následně dává najevo, že porozuměla, a nabídne možné synonymum v angličtině (mean), jehož správnost Táňa v překryvu replik potvrdí (řádky 30 a 31). Tím se zdá problém s významem slova tight-fisted vyřešen, Soňa následně začne odpovídat na položenou otázku (řádek 37 , celá odpověd' není z prostorových důvodů v transkriptu zachycena).

Podobně jako v ukázce 1 obsahují publikované konverzačněanalytické studie vždy podrobné transkripty společně s detailními rozbory průběhů vybraných sekvencí,

3 Zde je důležité zdůraznit, že v konverzační analýze výzkumník nepracuje s vnitřními kognitivními stavy mluvčích, místo toho se opírá o záznam a transkript a vychází z toho, co je pozorovatelné. $\mathrm{Na}$ interakci se tedy nahlíží jako na sociální problém. Proto zde neuvádíme, že Soňa slovo tight-fisted nezná nebo si není jista jeho významem. 
12 přičemž autoři se typicky zaměřují jak na úkony, které mluvčí v interakci provádějí, tak i na prostředky, kterými mluvčí dané úkony realizují. Všechny studie $v$ tomto přehledu se zaměřují na praktiky (tj. způsoby jednání, kterými mluvčí realizují dané úkony) použivané spolužáky $v$ interakci. Detailní popis těchto praktik typicky charakterizuje interakci, která použití dané praktiky předcházela, samotnou praktiku a také interakci, jež bezprostředně následovala. $V$ ukázce 1 je např́ílad možné pozorovat, jakými prostředky a $v$ jaké situaci studentka problematizovala význam slova z otázky, jakými způsoby studentky význam vyjednaly ${ }^{4}$ a přešly k zodpovídání otázky. Před sepsáním analýzy autoři v konverzační analýze podrobně procházejí pořízená data a vybírají sekvence zachycující předmětnou praktiku, do publikovaných studií pak běžně zařazují pečlivě vybrané sekvence zachycující praktiky použité mluvčími. Podrobná analýza těchto praktik je výstupem konverzačněanalytického výzkumu a představuje jeden ze způsobů, kterými je možné velmi podrobně rozebrat procesuální stránku interakce mezi spolužáky.

\section{Výběr a analýza studií}

Cílem této studie je podat přehled o zahraničních výzkumech interakce mezi spolužáky vedených $v$ tradici konverzační analýzy, konkrétně se soustředíme na metodologické charakteristiky a zaměření zahraničních studií. Takových studií existuje obrovské množství a každý výběr bude nutně selektivní. $V$ této studii vycházíme z předpokladu, že k nejaktuálnějším zdrojům, kde lze nalézt kvalitní konverzačněanalytické studie interakce ve trídě, patří databáze Scopus. Ta indexuje takové edukačnělingvistické časopisy, jako např́klad Classroom Discourse nebo Linguistics and Education, které mají v popisu explicitně uvedeno, že uveřejňují konverzačněanalytické studie, a zároveň další edukačnělingvistické časopisy, jako třeba Applied Linguistics, The Modern Language Journal nebo Language and Education, ve kterých př́spěvky z konverzační analýzy běžně vycházejí (srov. s výběrem časopisů, ve kterých vycházejí studie z interakce ve tříě, u Skukauskaiteové et al., 2015). Celkově databáze Scopus indexuje kolem dvou tisíc lingvisticky a pedagogicky zacílených časopisů, ve kterých je možné pomocí klíčových slov hledat konverzačněanalytické studie zaměřené na interakci mezi spolužáky.

Vyhledávali jsme časopisecké studie, jejichž titulek, abstrakt nebo klíčová slova obsahují sousloví označující konverzační analýzu (conversation analysis), alespoň jeden $z$ výrazů pro vymezení interakce ve tř́́dě mezi žáky nebo studenty (class*, learner*, student ${ }^{*}$, pupil*) a současně alespoň jeden výraz pro interakci mezi spolužáky ve skupinách nebo dvojicích (peer*, group*, pair*). Takto jsme při hledání

4 Z ukázky je zřejmé, že vyjednávání významu je společná činnost. Po problematizování slova tight-fisted Soňou následovala Tánina parafráze, Táňa dále nabídla gesto a český překlad, které Soňa stvrdila přidáním synonyma $v$ angličtině. Uvedené podtrhují sociální povahu a pojetí interakce jako vzájemné pưsobení mluvčích. 
na konci srpna 2018 obdrželi 131 výsledků z let 2008-20185. Na základě titulku a abstraktu jsme z výběru vyřadili 96 studií. ${ }^{6}$ Vyloučili jsme studie zaměřené na interakci, jež nesouvisela se vzděláváním (např. v rodině, ve skupině turistů) nebo která probíhala v on-line prostředí či v předškolním vzdělávání. Dále jsme vyřadili ty studie, které se týkaly činností vyučujících, asistentů pedagoga nebo zkoušejících. Dále jsme nezařadili jednu studii, která byla v japonštině, a jednu studii z časopisu, který nám nebyl dostupný7.

U všech zbývajících 35 studií jsme získali jejich plné texty, při jejichž pročítání jsme vyřadili dalších 7 studií z výše uvedených důvodů nebo proto, že vycházely pouze z některých aspektů konverzační analýzy (např. transkripční konvence), ale jejich teoretické a metodologické ukotvení bylo diametrálně odlišné. 8

Výše uvedeným postupem jsme dospěli k souboru 28 studií. Je třeba zdůraznit, že se rozhodně nejedná o vyčerpávající přehled všech konverzačněanalytických studií interakce mezi spolužáky: jistě by bylo možné najít další relevantní časopisecké studie, které nevyhověly našim formálním kritériím nebo které nejsou indexované v databázi Scopus, podobně jako existují monografie nebo disertační práce. I přes uvedená omezení vyvozujeme, že soubor studií, které zde představujeme, do značné míry odráží obecnější charakteristiky výzkumu v oblasti interakce mezi spolužáky, a proto považujeme za nosné tyto charakteristiky v přehledové studii představit.

U všech zbývajících 28 studií jsme vedle bibliografických údajů zaznamenávali především jejich metodologické aspekty (množství a charakter sbíraných dat) a zaměření (cíl, vyučovací předmět, stupeň vzdělávání, země sběru dat). Tyto údaje shrnujeme v tabulce 1 . Dále jsme sledovali hlavní zjištění těchto studií. Podle cílů studií, jejich východisek a hlavních zjištění jsme pak vytvářeli skupiny obdobně zaměřených studií, které prezentujeme $v$ druhé části následujícího oddílu společně se shrnutím některých zjištění.

\section{Přehled zahraničních studií}

Z přehledu studií v tabulce 1 vyplývá, že nejvíce jich pochází ze Spojených států amerických ( 9 studií) a ze severských států (4 z Finska, 3 ze Švédska), kde se konverzační analýza ustavila jako jeden z přistupů k výzkumu interakce v edukačním prostředí. Pokud jde o úroveň vzdělávání, je patrné, že většina vybraných studií pochází z vysokého školství (18 prríspěvků), zbývající jsou z primárního nebo sekundárního

Tento interval volíme s ohledem na to, že z dřívějšího období (1988-2007) databáze Scopus obsahuje pouze 27 výsledkủ. Podáváme zde tedy přehled o studiích publikovaných v posledních deseti letech.

6 Vysoký podíl vyřazených studií je dán také tím, že řada abstraktů zahrnuje i jméno nakladatele, jež obsahuje slovo „group“ (např. Taylor \& Francis Group), což způsobilo, že se ve výsledcích objevila také řada nerelevantních studií.

7 Jedná se o časopis Journal of Language and Literature, který již patrně neexistuje.

8 Např́klad se jednalo o kvantifikace nebo kategorizace určitých jevů bez jejich detailní analýzy. 
14 vzdělávání. Z vyučovaných předmětů nebo kurzů, ve kterých byla data sbírána, se vybrané studie zaměřují převážně na výuku jazyků, konkrétně angličtiny (10 studií), italštiny ( 2 studie), japonštiny ( 2 studie), finštiny ( 1 studie), němčiny ( 1 studie), prípadně se zabývají interakcí ve více jazykových předmětech ( 3 studie), převážně se jedná o cizí jazyky. $S$ výukou jazyků poměrně úzce souvisí i studie zaměřené na akademické psaní, na multikulturní výchovu nebo na integrovanou výuku dějepisu a angličtiny. Takto početné zastoupení studií orientovaných na výuku jazyků lze vysvětlit tím, že jedním z cílů takové výuky je naučit žáky nebo studenty v daném jazyce interagovat, přitom to, jak interagují, odpovídá zaměření konverzačněanalytického výzkumu na praktiky používané mluvčími v interakci. Vedle jazyků je ještě ve vybraných studiích zastoupena výuka fyziky (2 studie) a kurz plánovaní a hodnocení pro budoucí učitele (1 studie). Ostatní tři studie se zaobírají interakcí v jiných prostředích přesahujících tradiční vyučovací předměty (práce na domácích úkolech, badatelská výuka, výuka $v$ alternativní škole).

Pokud jde o zdroje dat, vychází převážná většina ( 25 z 28) studií z videonahrávek (případně doplněných audionahrávkami), pouze jeden př́spěvek (Al-Gahtani \& Roever, 2018) vychází výhradně z audionahrávek a u dvou studií (Barnes, 2016; Unamuno, 2008) z charakteristiky dat nelze jednoznačně určit, o jaký typ nahrávek se jedná. ${ }^{9}$ To, že se převážná část studií opírá o videonahrávky, lze vysvětlit tím, že audiovizuální záznam umožňuje hlouběji a podrobněji analyzovat praktiky, které spolužáci používají při interakci tváří v tvář. Některé studie se navíc tělesnými úkony nebo produkcí materiálních artefaktů (např. textu nebo obrázku) př́mo zabývají, takže videonahrávku z principu vyžadují. Z hlediska množství sbíraných dat některé studie (kupř. Niemi, 2014) představují a podrobně analyzují jednu vybranou epizodu; opačným extrémem jsou př́spěvky Ruska, Sahlströma a Pörnové (2017), kteří ve své studii vycházejí z 95 hodin videozáznamu, nebo Melanderové (2012), která vychází dokonce ze 140 hodin videozáznamů. $Z$ třetího sloupečku tabulky 1 je zřejmé, že řada autorů ve svých studiích přesnou délku výchozích dat neuvádí, protože se v podrobné analýze zaobírají jen několika krátkými a pečlivě vybranými sekvencemi. Ze studií, které délku výchozích záznamů explicitně uvádějí, jsme vypočítali medián 9 hodin videonahrávek. Taková délka se může jevit jako velmi krátká, je ale třeba zdůraznit, že výzkumníci v konverzační analýze pracují s podrobným přepisem pořízených nahrávek a směřují $k$ analytickému zobecnění ( $k$ tomu podrobněji např. Tůma, 2017a, s. 40-41). Uvedený počet navíc odpovídá zjištění ze staršího přehledu konverzačněanalytických studií interakce ve tř́dě u Seedhouse (2004, s. 87), podle kterého pro výzkum postačuji a běžně se používají nahrávky 5-10 vyučovacích hodin.

9 Z transkriptů lze dovodit, že spiše jde o audionahrávky. 


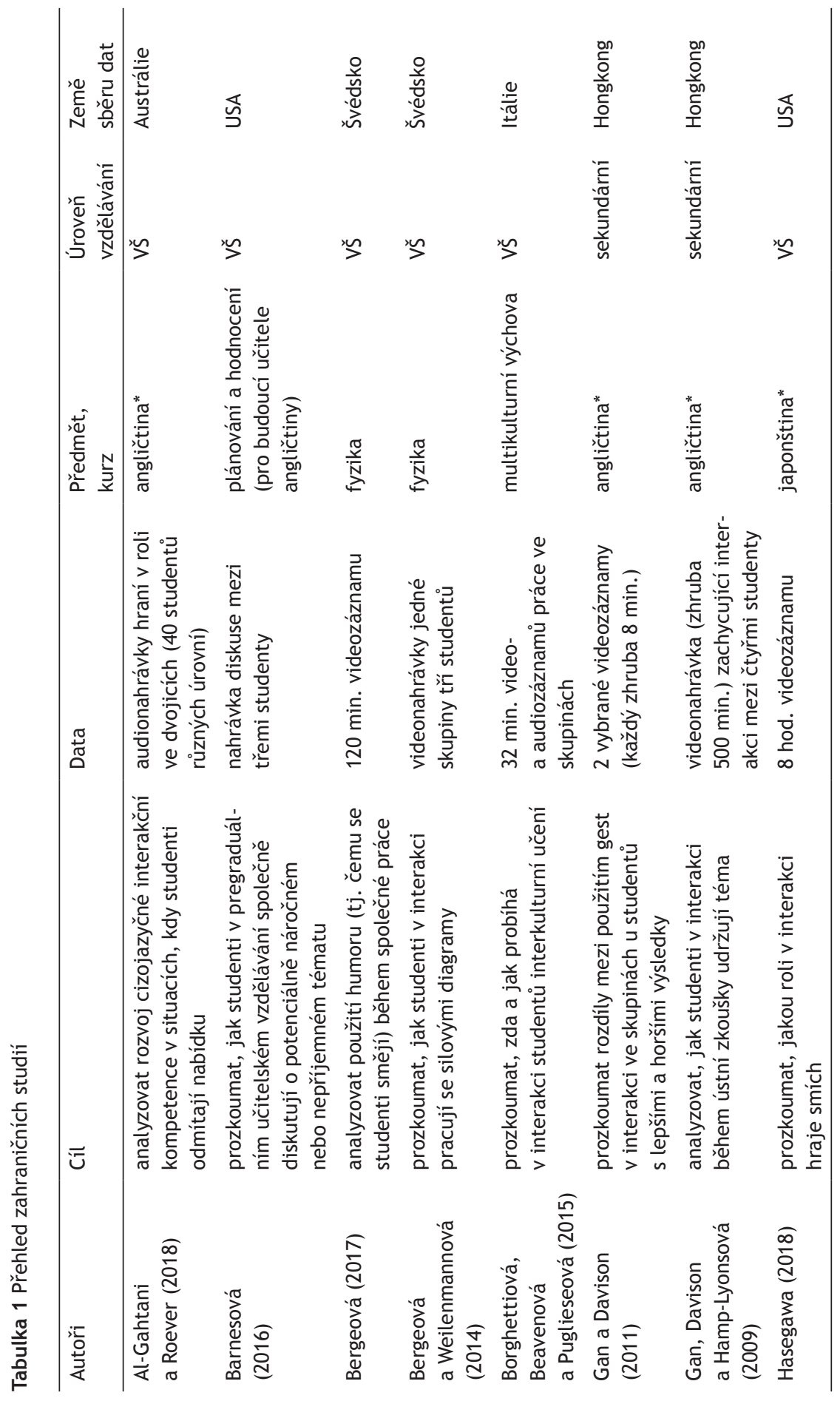


16

范

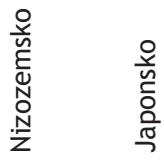

ڤั

$\stackrel{p}{\stackrel{y}{\rightleftarrows}}$

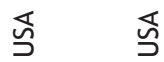

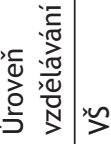

in

$\stackrel{\frac{2}{2}}{\frac{2}{5}}$

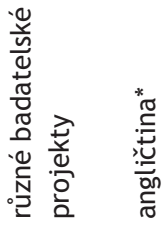

¿্ৰ

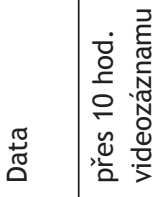

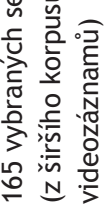

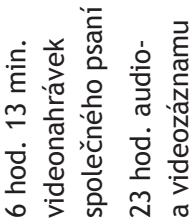

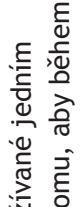

滳

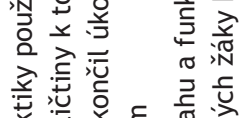

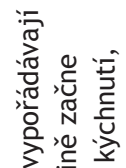

흔

至

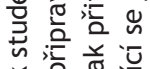

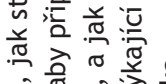

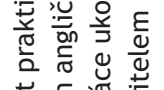

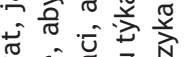

ग 는

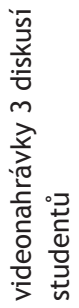

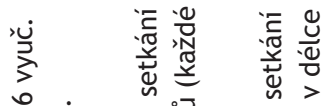

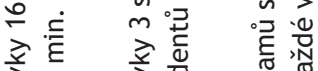

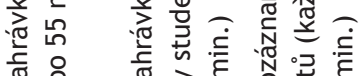

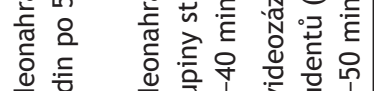

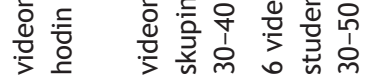

วิ)

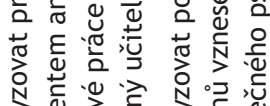

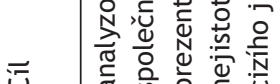

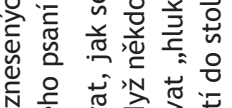

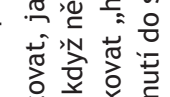

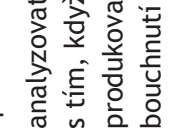

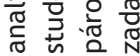

它 离 的

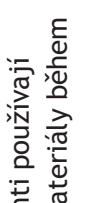

華

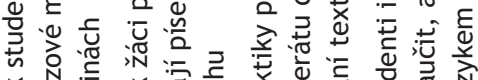

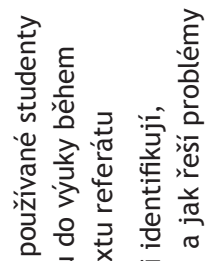

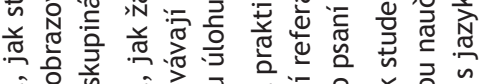

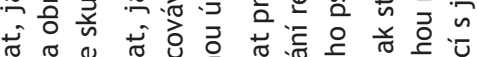

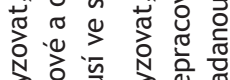

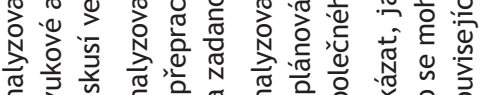

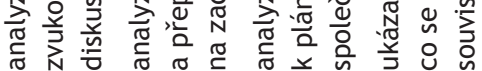

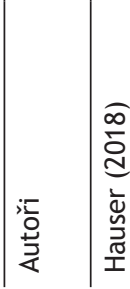

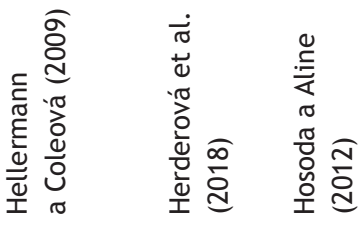

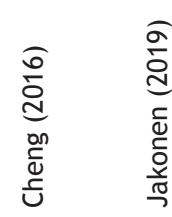

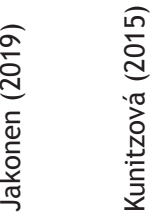

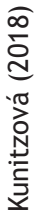




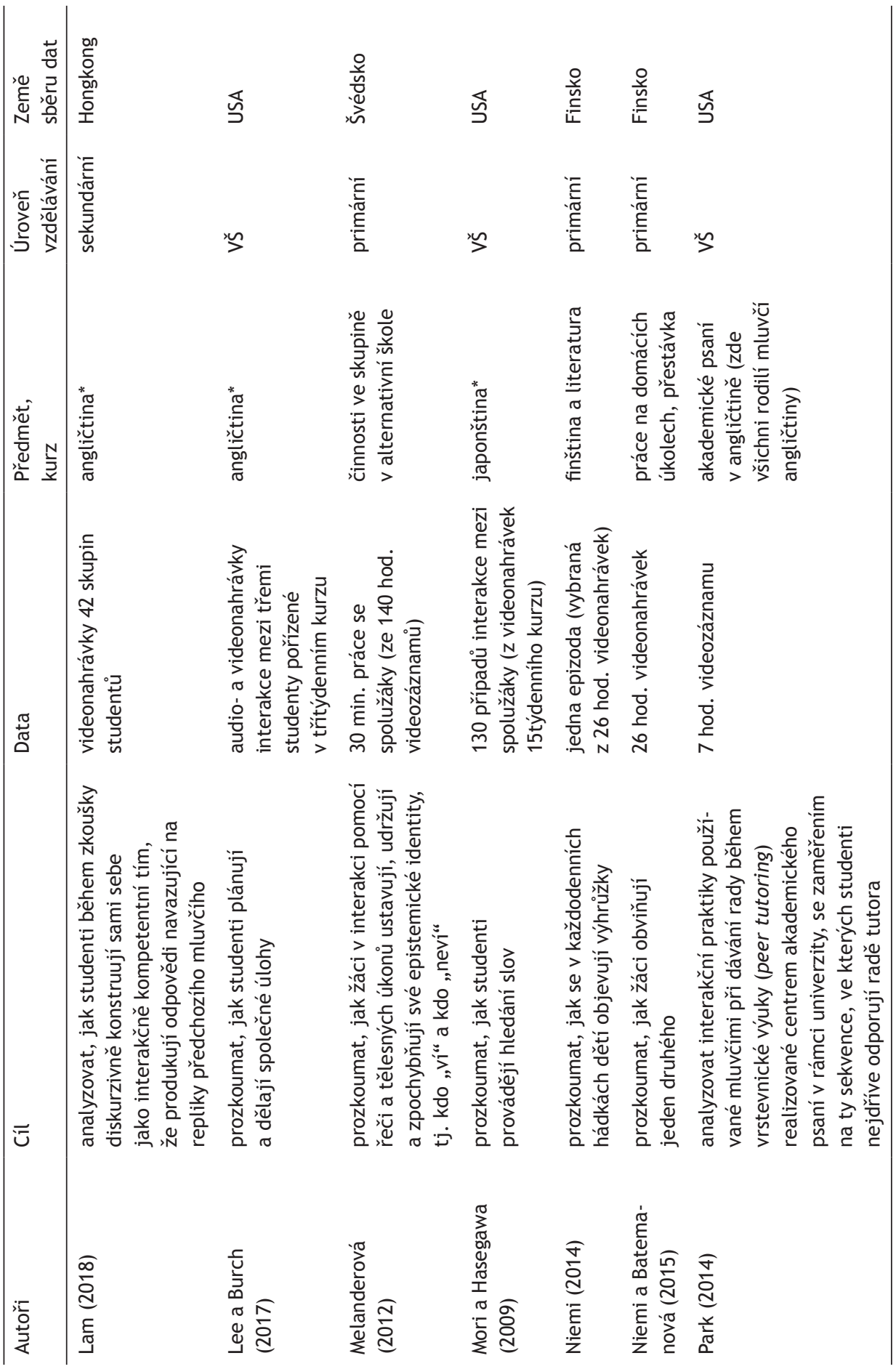


18

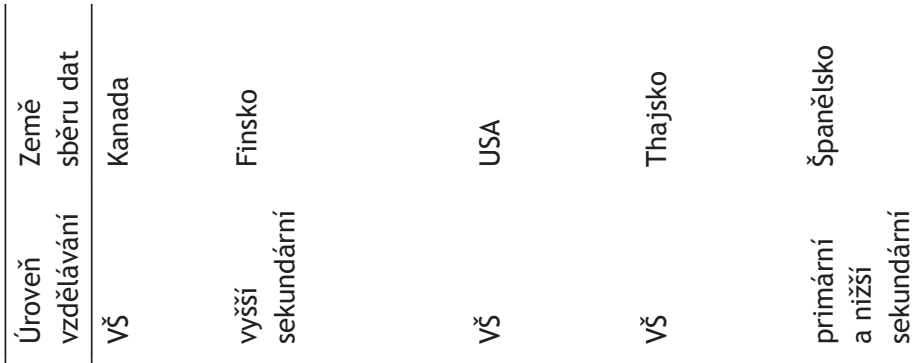

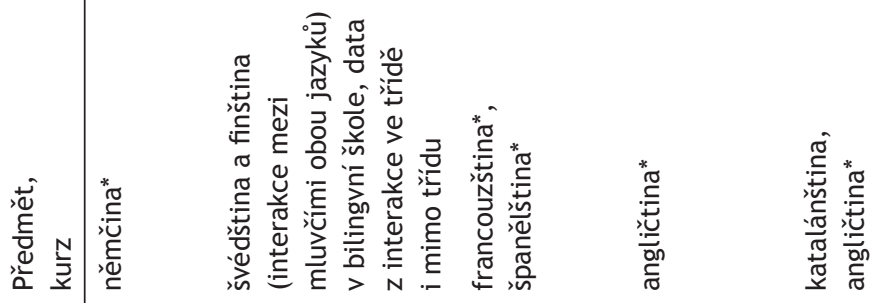

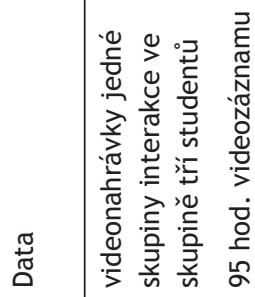

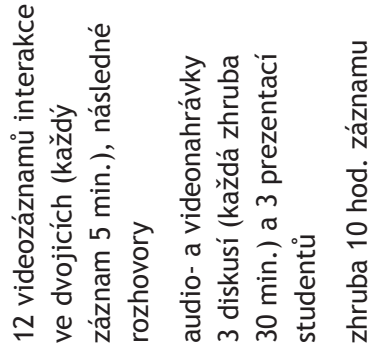

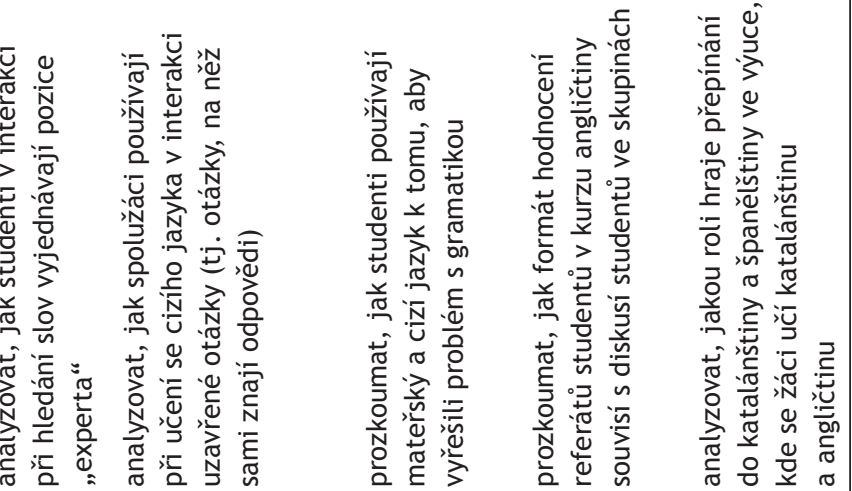

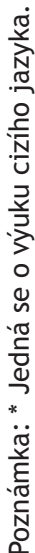


V následujících odstavcích podrobněji představíme jednotlivé skupiny studií. Konkrétně pojednáme o tom, jak spolužáci ve skupinách nebo dvojicích řeší zadané úlohy, jak během takové interakce dochází k učení se, jak vrstevníci jeden druhého vyučují a jak spolužáci v interakci používají tělesné, jazykové nebo materiální prostředky.

Řada studií z tabulky 1 analyzuje praktiky používané žáky a studenty při společném plánování nebo řešení zadané úlohy. Například ukazují, jak při společné produkci textu mluvčí diskutují o obsahu psaného textu, navrhují možné formulace, překládají z nebo do mateřského jazyka, píšou a zároveň čtou vznikající text a diskutují o vhodnosti použitých formulací (Herder et al., 2018; Jakonen, 2019; Kunitz, 2015; Sundrarajun \& Kiely, 2010). Podobně ve výuce fyziky studenti společně kreslí silový diagram, zanášejí a interpretují síly působící na zakreslená tělesa a opravují chybně zakreslené vektory (Berge \& Weilenmann, 2014). Některé studie se zabývají specificky tím, jak žáci a studenti společně rozmýšlejí pracovní postup pro řešení zadaného úkolu. Tyto studie ukazují, jak studenti v interakci interpretují původní zadání úlohy, jak dosahují shody v tom, jaký zvolí další postup a jaké volby činí, a také to, jak v interakci řeší vzniklá nedorozumění (Lee \& Burch, 2017; srov. s plánováním při psaní referátu u Kunitzové, 2015). Jiní autoři rozkrývají, jak studenti udržují, vyjednávají a mění téma probíhající interakce (Gan et al., 2009) nebo jak při diskusi o citlivých či nepřijemných tématech studenti hledají spíše shodu než rozdílnost názorů a pohledů (Barnes, 2016). Tyto studie podrobně rozebírají, jak mluvčí ve skupině řeší úkol, plánují postup, mění téma diskuse nebo opravují nedorozumění.

Druhou oblastí, která je v tradici konverzační analýzy silně zastoupena, je učení se $v$ interakci. Studie v našem souboru se týkají výhradně výuky cizích jazyků (převážně angličtiny, ale také italštiny a japonštiny) a multikulturní výchovy, v nichž je vztah mezi jazykovou interakcí a učením se jazyka velmi úzký: lze předpokládat, že alespoň část kognitivních procesů, a tedy i učení se, je vnějšímu pozorovateli přístupná skrze průběh interakce. Studie např́klad ukazují, že žáci a studenti během mluvení ve dvojicích vyjadřují vlastní významy, k čemuž někdy nemají k dispozici jazykové prostředky. Mori a Hasegawa (2009) analyzují, jak studenti při mluvení iniciují a provádějí opravné sekvence typu hledání slov a jak učebnice slouží i jako zdroj pro učení se nových jazykových prostředků. Obdobně se při společném psaní studenti explicitně zaměřují na shodu rodů v italštině: student, který píše, vyjádří nejistotu nad gramatickou správností zapisované fráze, načež někdo ze studentů navrhne tvar, který skupina schválí a student zapíše (Kunitz, 2018). Obě tyto studie podrobně analyzují, jak studenti společně vytvářejí, dokončují nebo opravují věty v cizím jazyce, přičemž cílí na problematické jazykové prostředky (slovní zásoba, gramatické jevy), které společně produkují. Podobně Borghettiová et al. (2015) ukazují, jak studenti v interakci společně produkují sekvence, ve kterých: 1) vztahují to, co nejprve považují za podivné, k vlastním zkušenostem a k tomu, co již znají; 2) společně vysvětlují nový fenomén, přičemž sdílejí to, jak mu rozumějí; a 3) přizpůsobují se tomu, co řekli ostatní. Autorky vyvozují, že v těchto typech sekvencí probíhá interkulturní učení. 
Na pomyslnou hranici mezi první a druhou výše uvedenou skupinou je možné situovat studie, které se věnují rozvoji tzv. interakční kompetence u žáků a studentů (Hall \& Pekarek Doehler, 2011). Tyto studie podrobně analyzují, jak mluvčí interagují, a zároveň typicky zohledňují časové hledisko, tj. jak se žáci a studenti cizího jazyka v čase učí realizovat vybrané úkony v cizím jazyce. Ústřední oblastí zájmu těchto studií jsou především pragmalingvistické aspekty. Autoři tedy napríklad analyzují, jak studenti odmítají nabídku (Al-Gahtani \& Roever, 2018), jak v rozhovoru navazují na repliky předchozího mluvčího (Lam, 2018) nebo jak ukončují práci nad zadanou úlohou (Hellermann \& Cole, 2009).

V souvislosti s rozvojem interakční kompetence u žáků a studentů a s učením se $v$ interakci lze uvést další typ studií, které se zabývají výukou mezi vrstevníky (peer tutoring, peer instruction). Napríklad Rusk et al. (2017) rozebírají, jak studenti při vrstevnické výuce finštiny nebo švédštiny použivají otázky, na které sami znají odpovědi, a jak tyto sekvence mohou vést k učení se. Jiná studie ukazuje, jak vrstevničtí tutoři a studenti, kteří se s nimi setkávají v centru pro akademické psaní, vyjednávají své role v sekvencích, ve kterých studenti nejprve odporují radám vrstevnického tutora (Park, 2014).

S tím, jak mluvči v interakci kladou a zodpovídají otázky, úzce souvisí problematika epistemiky, tedy vědění a nevědění (Heritage \& Clayman, 2010, s. 24-25). Pokud spolužáci pracují se znalostmi (kupř. cizího slova, pravidla), dochází přirozeně $k$ tomu, že se (ne)vědění nějak odráží v interakci. Studie $z$ výuky němčiny např́iklad ukazuje, jak se jeden student při hledání slov staví do pozice „experta“ (nikoli jen tím, že dané slovo zná, ale také třeba tím, že použije notebook nebo učebnici), který pomůže hledané slovo nalézt (Reichert \& Liebscher, 2012). Podobně Melanderová (2012) analyzuje, jak žáci v alternativní škole dávají najevo svou epistemickou identitu, a to nejen verbálně (např. tím, že mluví o sobě nebo druhých jako o těch, kteři vědí nebo umějí), ale i tělesně (kupř. „podřízeným“ držením těla, pokud poslouchají spolužáka, který něco vysvětluje). Naproti tomu Hauser (2018) na datech z výuky angličtiny ukazuje, jak se studenti v interakci staví do role „ne-experta“ např́íklad tím, že cílový tvar říkají nejistě nebo pochybují o tom, co právě řekli. Společné těmto studiím je, že nahližejí na vědění a nevědění v interakci dynamicky: z hlediska spolupráce ve skupině nebo dvojici nestačí, že mluvčí vyjádří, že něco (ne)ví. Spolužáci mohou takové tvrzení ignorovat, popř́t či stvrdit svým následným jednáním a samozřejmě pozice a přijetí toho, že ve skupině někdo (ne)disponuje znalostí nebo prístupem ke znalosti, se může v čase měnit (např. Melander, 2012, s. 242-244).

Další studie $v$ našem souboru se věnují tělesným prostředkưm v interakci. ${ }^{10}$ Dvě studie z vysokoškolského prostředí se zabývají zdánlivě méně vážnými aspekty in-

10 Termín tělesné prostředky zde používáme v souladu s konverzačněanalytickým zájmem o to, jak mluvčí v interakci koordinují používání různých jazykových, tělesných a materiálních prostředků. Nepřikláníme se tedy k používání termínu neverbální ( v protikladu k označení verbální) prostředky, které předpokládá určitou umělou hierarchii mezi těmito typy prostředkủ (Kimura et al., 2018, s. 3-4; Streeck et al., 2011, s. 7-12). 
terakce: rolí smíchu (Hasegawa, 2018) a humoru (Berge, 2017) v interakci. Autoři obou studií ukazují, že studenti používají smích a humor téměř výhradně ve vztahu k vyučovanému předmětu: ve fyzice používají humor k vyjádření, že něco je zřejmé, obtížné, špatné nebo absurdní (Berge, 2017); obdobně ve výuce japonštiny se smějí, když interpretují zadanou činnost, používají didaktické materiály, dávají si najevo, jaké pozice aktuálně zaujímají a na co se zaměřují (Hasegawa, 2018). Další studie se zabývají jinými tělesnými prostředky. Např́klad Gan a Davison (2011) při zkoumání, jak studenti angličtiny používají gesta, zjistili, že studenti s lepšími výsledky svá gesta pečlivě synchronizují s tím, jak mluví a jak se střídají, zatímco studenti s horšími výsledky použivají gesta k vyjádření problémů s produkcí cílového jazyka a související nejistoty. Jiná studie cílí na to, jak mluvčí v interakci interpretují zvuky produkované jinými mluvčími, jako například kašlání, kýchnutí nebo bouchnutí do stolu. Autoři zjistili, že aktuální mluvčí ve skupině se viditelně vztahuje $k$ tomu, když někdo ze spolužáků produkuje takový zvuk, třeba tím, že přeruší svou aktuální repliku; mluvčí zároveň produkují tyto tělesné zvuky s ohledem na probíhající interakci, kupříkladu kýchnou až po ukončení probíhající výměny (Hosoda \& Aline, 2012). Tyto studie dokládají, jak úzce souvisejí některé pozorovatelné tělesné projevy s průběhem interakce.

Vedle tělesných prostředků hrají v interakci důležitou roli i prostředky jazykové. Patři sem například studie zabývající se problematikou střídání kódů (code-switching, code-alteration), tedy jazykové chování, ve kterém mluvčí v interakci přejdou z jednoho jazyka nebo dialektu do jiného. Tyto studie dokládají, že spolužáci střídají kódy smysluplně a že zejména používání mateřského jazyka ve výuce cizího jazyka má své opodstatnění, kupříkladu přepnutí do mateřského jazyka slouží k tomu, aby se spolužáci dohodli na postupu řešení úkolu (Unamuno, 2008) nebo aby vyjasnili gramatické nesrovnalosti (Scott \& Fuente, 2008), přičemž samotný úkol vyřeší v cizím jazyce.

Některé studie se zabývají takovými jevy, které se ve frontální výuce rízené učitelem běžně nevyskytují. Jedná se například o to, jak se děti hádají a jak si v interakci vzájemně vyhrožují (Niemi, 2014) nebo jak jeden druhého obviňují (Niemi \& Bateman, 2015). Na těchto studiích z primárního vzdělávání je zajímavé především jejich zaměření na každodenní verbální agresi v interakci mezi dětmi a také to, jak toto chování začleňují do prostředí školy a třídy.

Poslední v našem souboru je analýza toho, jak studenti používají zvukové a obrazové materiály (Cheng, 2016). Tuto studii by bylo možné přiřadit k příspěvkům, které se týkají řešení úkolu, učení se v interakci nebo rozvíjení interakční kompetence u studentů, nicméně autorka použila ve výuce angličtiny autentické nahrávky, které předtím analyzovala pomocí konverzační analýzy, a prvky konverzační analýzy také využila k tomu, aby si studenti na daných nahrávkách uvědomili, jak lze v angličtině vyjádřit nesouhlas. Studie tedy ukazuje, že konverzační analýzu lze uplatnit také ve vzdělávání ( $k$ dalším možnostem viz Tưma, 2017a, s. 165-167), a zároveň pomocí konverzační analýzy dokládá, jak studenti angličtiny na pořizených záznamech s takto připravenými materiály pracují. 
Výše představené charakteristiky konverzačněanalytických studií interakce mezi spolužáky $v$ našem souboru nejprve shrneme, přičemž poukážeme na některé limity našeho přehledu, upozorníme na výzkumem opomíjené oblasti a vyvodíme několik závěrů pro výzkum, který může na uvedené zahraniční studie navázat. V závěru textu upozorníme na vybrané přesahy konverzačněanalytického výzkumu do pedagogiky.

Již na začátku oddílu 3 jsme poznamenali, že většina konverzačněanalytických studií $v$ našem souboru pochází z výuky (cizích) jazyků. Je potěšující, že se jedná o studie $z$ geograficky a kulturně různorodých prostředí, nicméně z evropských států převládají ty severské. $V$ této souvislosti je možné problematizovat, do jaké míry jsou poznatky z takto jazykově a kulturně odlišných prostředí přenositelné do středoevropského vzdělávání a do jaké míry lze zjištění z těchto výzkumů vzhledem k odlišným sociokulturním podmínkám a zvyklostem stavět vedle sebe. Pokud by predmětem výzkumu bylo, jaká je komunikační výchova $v$ dané zemi, jak jsou žáci a studenti hodnoceni, jaké jsou rozdíly $v$ komunikaci mezi různými skupinami žáků a studentů (pohlaví, etnicita, prospěch apod.) nebo jak často žáci či studenti pracují ve skupinách, pak by určitě bylo nutné brát sociokulturní podmínky a další kontextové proměnné $v$ úvahu. Nicméně, jak jsme uvedli v prvním oddílu, $v$ konverzační analýze jsou předmětem výzkumu praktiky, které mluvči v interakci sami používají. $\checkmark$ této souvislosti existuje řada různých pohledů na prostředí a kontext, ve kterých se interakce odehrává (Kunitz \& Markee, 2017). Je možné říci, že v konverzační analýze výzkumník bere $v$ úvahu především ty aspekty kultury a prostředí, ke kterým se mluvčí sami pozorovatelně vztahují v interakci, kategorie jako gender, etnicita nebo hodnocení učitelem proto tedy do analýzy a priori nevstupuji11. Konverzační analýza tedy cílí na samotné praktiky používané mluvčími, které jsou univerzálnějšího charakteru a které mohou mít mluvčí $\mathrm{k}$ dispozici při interakci napřič různými prostředími (k tomu srov. Beach, 1990; de Kok, 2008). Ukázalo se např́klad, že postupy pro stř́íání mluvčích, které identifikovali a podrobně popsali Sacks, Schegloff a Jeffersonová (1974) na nahrávkách každodenních rozhovorů mluvčích americké angličtiny, stejně tak používají i mluvčí jiných jazyků (Clift, 2016, s. 95-96); tyto praktiky jsou univerzálně platné pro interakci mezi dvěma i více mluvčími. $Z$ této konverzačněanalytické perspektivy je tedy možné srovnávat zjištění ze sociokulturně $\mathrm{i}$ jazykově různých prostředí, z práce ve dvojicích a ve skupinách ${ }^{12}$ nebo z různých typů škol, protože v konverzačněanalytickém výzkumu vystupují do popředí praktiky,

11 Např́klad při analýze ukázky 1 jsme uvedli, že studentky pracovaly s otázkou ze zadání v učebnici, což je doložitelné $z$ toho, že se na učebnici dívaly, a z toho, že Táňa přečetla část otázky prrímo z učebnice, čímž se $\mathrm{k}$ ní pozorovatelně vztahovala. Pokud by se studentky do učebnice nedívaly, nečetly z ní otázku a nijak s ní nemanipulovaly, nevstupovala by učebnice jako materiální artefakt do analýzy, stejně jako do ní nevstupovaly další faktory, jako třeba pohlaví, prospěch, socioekonomický status nebo hodnocení učitelky po aktivitě.

12 Konverzačněanalytické studie obecně neproblematizují, zda se jedná o interakci mezi dvěma, nebo více mluvčími. Kupríkladu Hasegawa (2018) analyzuje, jak spolužáci používali smích v interakci, přičemž uvádí ukázky z práce ve dvojicích i trojicích a mezi těmito - z pohledu sociální psychologie odlišnými - situacemi nediferencuje. 
které mluvčí sami užívají. Je zřejmé, že pokud by výzkum interakce mezi spolužáky byl veden $v$ jiné tradici, mohlo by být nezbytné $\mathrm{k}$ prostř̌edí přihližet jiným způsobem ( $k$ prehehledu různých tradic výzkumu interakce ve tř́dě viz např. Markee, 2015).

Z tabulky 1 vyplývá, že výzkum interakce mezi spolužáky $v$ nejazykových předmětech je poměrně omezený. Přitom existující studie ukazují potenciál konverzační analýzy napríklad pro podrobné postihnutí toho, jak studenti fyziky společně $v$ interakci zakreslují diagramy a řeší zadanou úlohu (Berge \& Weilenmann, 2014). Zdá se, že konverzační analýza pro výzkum toho, jak spolužáci v různých předmětech pracují s pomůckami a učebními materiály, stejně jako to, jak společně vytvářejí, interpretují nebo používají různé artefakty, stále čeká na své plné využití.

Podali jsme přehled konverzačněanalytických studií, které se zaměřují na to, jak spolužáci ve skupinách nebo dvojicích plánují a řeší zadané úlohy, jak během takové interakce dochází $\mathrm{k}$ učení se (včetně osvojování cizího jazyka a rozvoje interakční kompetence u žáků a studentů), jak spolužáci jeden druhého vyučují a jak používají tělesné, jazykové nebo materiální prostředky. Tyto studie společně dokládají, že interakce mezi spolužáky typicky probíhá nelineárně a dynamicky: spolužáci opravují nedorozumění, odbočují $\mathrm{k}$ jiným nebo dílčím tématům a vracejí se $\mathrm{k}$ zadání, které (re)interpretují. Autoři studií dále dokládají, že kroky jednotlivců (např. odbočení $\mathrm{k}$ jinému tématu $v$ diskusi) jejich spolužáci následně v interakci stvrzují, modifikují nebo ignorují, což udává další směr, kterým se může interakce ubírat.

Uvedená zjištění z výzkumu probíhající interakce je možné dát do protikladu k některým modelům řešení učebních úloh vycházejících z kognitivní psychologie, které předpokládají, že řešení probíhá lineárně a podle předem definovaných kroků (Čižková, 2002; Knecht, 2014, s. 74; srov. Češková \& Knecht, 2016). Některé tyto modely navíc předpokládají, že všichni spolužáci interpretují zadání stejně a pracují v souladu s ním. Např́klad při řešení problému podle Sternberga (2009, s. 386-389) po fázi identifikace problému následuje definice problému a následně vytvoření strategie řešení problému. Uvedené schéma (Sternberg, 2009, s. 387) nepředpokládá, že by se žáci během vytváření strategie řešení problému mohli vrátit zpět $k$ identifikování nebo definování problému, což je v rozporu s některými zjištěními ze studií, které zkoumají probíhající interakci v tradici konverzační analýzy. Kupř́kladu Lee a Burch (2017) dokládají, že spolužáci během plánování a řešení problému postup vyjednávají neustále. Studie, jejichž přehled jsme zde uvedli, tedy ukazují, jak může konverzačněanalytický výzkum přispět k poznání toho, jak konkrétně spolužáci postupují při řešení učebních úloh (srov. se shrnutím pedagogickopsychologických východisek u Mareše, 2013, s. 378-382).

Mezi základní oblasti zájmu v konverzační analýze patří, jak se mluvčí v interakci střídají. Výzkumy ukazují, že interakci ve frontální výuce typicky řídí učitel (srov. s tř́složkovou výměnou typu IRE u Mehana, 1979; nicméně ne vždy probíhá interakce ve frontální výuce $v$ těchto třisložkových výměnách, srov. Tůma, 2017a, s. 59-86). Konverzačněanalytické studie, o nichž jsme zde podali přehled, tuto pestrost podob interakce potvrzují. Za pozornost stojí mimo jiné studie Ruska et al. (2017), kteří se zaměřili na to, jak vrstevníci jeden druhého vyučují cizí jazyk a jak 
24 při tom kladou otázky, na které sami již znají odpověd', a do vrstevnické interakce zavádějí třísložkové výměny (IRE), které jsou popsány ve frontální výuce. Zjištění $z$ tohoto konverzačněanalytického výzkumu naznačují, že uzavřené otázky a třísložkové výměny mají ve výuce své přirozené místo: vrstevníci v interakci dosahují cílů vycházejících z povahy dané interakce, např́klad pomocí uzavřených otázek a třisložkových výměn objasňují pravidla nebo významy slov. Uvedené lze dát do protikladu $\mathrm{k}$ více pedagogicky a normativně laděným tradicím, kupř́kladu proponenti tzv. dialogického vyučování požadují zavádět do výuky více „autentických“ otázek, tedy těch, které se vyskytují mimo školu, respektive ty, na které druhý mluvčí nezná odpověd' (např. Šed'ová et al., 2016, s. 30), a v této souvislosti kritizují př́tomnost tř́isložkových sekvencí typu IRE ve frontální výuce, mimo jiné kvưli řídící roli učitele (Šed'ová et al., 2016, s. 39). Výzkumník v konverzační analýze ale obvykle nezaujímá podobné normativní pozice a zaměřuje se na to, jak mluvčí interagují a $\mathrm{k}$ čemu se $\checkmark$ interakci pozorovatelně vztahují.

Z výše uvedeného vyplývají vazby mezi pedagogikou, oborovou didaktikou a konverzační analýzou. Mikroanalytický př́stup, který představuje např́klad konverzační analýza, může teoreticky a metodologicky obohatit stávající výzkum v pedagogice a didaktice, kupríkladu svým důrazem na exploraci a podrobnou deskripci, procesuální stránku interakce nebo na postupy uplatňované samotnými mluvčími. Empiricky mohou poznatky z konverzačněanalytických výzkumů obohatit a doplnit stav poznání v pedagogice a oborové didaktice - pomocí konverzační analýzy totiž mohou výzkumníci zodpovědět otázky, jako např́klad: Jak plní žáci a studenti učební úlohy během párové nebo skupinové práce? Jak se uči jeden od druhého v interakci? Jaké jazykové, tělesné a materiální prostředky spolužáci v interakci používají a jak? Zde představené studie některé odpovědi na tyto otázky nabízejí.

Jedním z cílů projektu Interakce ve frontální výuce a skupinové práci v hodinách angličtiny na střední škole, při jehož řešení tento text vznikl, je zodpovědět některé výše nastíněné otázky. $V$ měsících září-listopad 2018 jsme $v 18$ hodinách angličtiny u pěti různých vyučujících nasbírali 1585 min. videonahrávek a 2729 min. audionahrávek interakce ve tř́dě ${ }^{13}$, které budeme $v$ následujících dvou letech řešení projektu analyzovat. Zjištění z našich analýz přispějí ke zde prezentovaným výzkumům a rozšírí záběr konverzačněanalytických studií interakce mezi spolužáky o data pocházející z výuky angličtiny v Česku.

\section{Poděkování}

Děkujeme dvěma anonymním recenzentům za podnětné připomínky, které pomohly zkvalitnit tento rukopis. Poděkování patří také Michaele Píšové, Tamah Sherman a Jakubu Mlynářovi za cenné komentáře a rady k předchozím verzím rukopisu.

13 Jedná se o výuku angličtiny ve 4. ročnících v pěti různých školách v Brně a jeho blízkém okolí. 


\section{Literatura}

*Al-Gahtani, S., \& Roever, C. (2018). Proficiency and preference organization in second language refusals. Journal of Pragmatics, 129, 140-153.

Arnold, K.-H., Sandfuchs, U., \& Wiechmann, J. (Eds.). (2009). Handbuch Unterricht (2. vyd.). Bad Heilbrunn: Klinkhardt.

Auer, P. (2014). Jazyková interakce (J. Nekvapil, P. Kaderka, M. Nekula, V. Dovalil, I. Vasiljev, \& M. Sloboda, přel.). Praha: Nakladatelství Lidové noviny.

*Barnes, M. E. (2016). Recognizing spaces of dissensus in English teacher education. English Teaching: Practice \& Critique, 15(2), 190-207.

Beach, W. A. (1990). Searching for universal features of conversation. Research on Language and Social Interaction, 24(1-4), 351-368.

*Berge, M. (2017). The role of humor in learning physics: A study of undergraduate students. Research in Science Education, 47(2), 427-450.

*Berge, M., \& Weilenmann, A. (2014). Learning about friction: Group dynamics in engineering students' work with free body diagrams. European Journal of Engineering Education, 39(6), 601-616.

Betáková, L. (2010). Discourse and interaction in English language teaching. Praha: PedF UK.

*Borghetti, C., Beaven, A., \& Pugliese, R. (2015). Interactions among future study abroad students: Exploring potential intercultural learning sequences. Intercultural Education, 26(1), 31-48.

Clift, R. (2016). Conversation analysis. Cambridge: Cambridge University Press.

Černá, M. (2005). ICT in teacher education: Extending opportunities for professional learning. Pardubice: Univerzita Pardubice.

Češková, T. (v rec. řízení). Interakce při řešení problémově orientovaných úloh ve výuce přírodovědy. Orbis scholae.

Češková, T., \& Knecht, P. (2016). Analýza problémově orientovaných výukových situací ve výuce prírodovědy. Orbis scholae, 10(2), 93-115.

Čížková, V. (2002). Příspěvek k teorii a praxi problémového vyučování. Pedagogika, 52(4), 415-430.

de Kok, B. C. (2008). The role of context in conversation analysis: Reviving an interest in ethno-methods. Journal of Pragmatics, 40(5), 886-903.

*Gan, Z., \& Davison, C. (2011). Gestural behavior in group oral assessment: A case study of higher- and lower-scoring students. International Journal of Applied Linguistics, 21(1), 94-120.

*Gan, Z., Davison, C., \& Hamp-Lyons, L. (2009). Topic negotiation in peer group oral assessment situations: A conversation analytic approach. Applied Linguistics, 30(3), 315-334.

Garfinkel, H. (1967). Studies in ethnomethodology. New Jersey: Prentice Hall.

Hall, J. K., \& Pekarek Doehler, S. (2011). L2 interactional competence and development. In J. K. Hall, J. Hellermann, \& S. Pekarek Doehler (Eds.), L2 interactional competence and development (s. 1-19). Bristol: Multilingual Matters.

*Hasegawa, A. (2018). Understanding task-in-process through the lens of laughter: Activity designs, instructional materials, learner orientations, and interpersonal relationships. The Modern Language Journal, 102(1), 142-161.

*Hauser, E. (2018). Being a non-expert in L2 English: Constructing egalitarianism in group preparation work. Hacettepe Egitim Dergisi, 33(Special Issue), 93-112.

*Hellermann, J., \& Cole, E. (2009). Practices for social interaction in the language-learning classroom: Disengagements from dyadic task interaction. Applied Linguistics, 30(2), 186-215.

*Herder, A., Berenst, J., de Glopper, K., \& Koole, T. (2018). Nature and function of proposals in collaborative writing of primary school students. Linguistics and Education, 46, 1-11.

Heritage, J., \& Clayman, S. (2010). Talk in action: Interactions, identities, and institutions. Chichester: Wiley-Blackwell.

*Hosoda, Y., \& Aline, D. (2012). Doing being interrupted by noise as a resource in second language interaction. Journal of Pragmatics, 44(1), 54-70. 
*Cheng, T.-P. (2016). Authentic L2 interactions as material for a pragmatic awareness-raising activity. Language Awareness, 25(3), 159-178.

*Jakonen, T. (2019). The integration of content and language in students' task answer production in the bilingual classroom. International Journal of Bilingual Education and Bilingualism, 22(4), 428-444.

Janík, M. (2017). Jak učitelé německého jazyka uživají ve výuce angličtinu. Pedagogická orientace, 27(1), 104-135.

Jarkovská, L. (2013). Gender před tabulí. Etnografický výzkum genderové reprodukce $v$ každodennosti školní třídy. Praha: SLON.

Kasíková, H. (2017). Kooperativní učení na školách: tři pohledy, tři výhledy. Pedagogika, 67(2), 106-125.

Kimura, D., Malabarba, T., \& Hall, J. K. (2018). Data collection considerations for classroom interaction research: A conversation analytic perspective. Classroom Discourse, 9(3), 185-204.

Knecht, P. (2014). Příležitosti k rozvíjení kompetence $k$ řešení problémů $v$ učebnicích a ve výuce zeměpisu. Brno: MU.

Králová, J. (2017). Analysis of learner-learner interaction in English as a foreign language teaching [diplomová práce]. Brno: FF MU.

Kratochvíl, M. (1987). Charakteristika párového vyučování a učení a jeho vliv na učební výkon prospěchově slabších žáků. Pedagogika, 37(1), 23-34.

*Kunitz, S. (2015). Scriptlines as emergent artifacts in collaborative group planning. Journal of Pragmatics, 76, 135-149.

*Kunitz, S. (2018). Collaborative attention work on gender agreement in Italian as a foreign language. The Modern Language Journal, 102(S1), 64-81.

Kunitz, S., \& Markee, N. (2017). Understanding the fuzzy borders of context in conversation analysis and ethnography. In S. Wortham, D. Kim, \& S. May (Eds.), Discourse and education: Encyclopedia of language and education (3. vyd., s. 15-27). Cham: Springer.

"Lam, D. M. K. (2018). What counts as "responding"? Contingency on previous speaker contribution as a feature of interactional competence. Language Testing, 35(3), 377-401.

*Lee, J., \& Burch, A. R. (2017). Collaborative planning in process: An ethnomethodological perspective. TESOL Quarterly, 51(3), 536-575.

Majcík, M. (2018). Postupy, které učitelé volí ve vztahu k žákovské chybě při interakci s celou třídou. Pedagogická orientace, 28(3), 472-495.

Maňák, J. (2003). Nárys pedagogiky. Brno: MU.

Mareš, J. (Ed.). (2003). Sociální opora u dětí a dospívajících III. Hradec Králové: Nucleus.

Mareš, J. (2013). Pedagogická psychologie. Praha: Portál.

Markee, N. (Ed.). (2015). The handbook of classroom discourse and interaction. Chichester: John Wiley \& Sons.

Mehan, H. (1979). Learning lessons: Social organization in the classroom. Cambridge: Harvard University Press.

*Melander, H. (2012). Transformations of knowledge within a peer group: Knowing and learning in interaction. Learning, Culture and Social Interaction, 1(3), 232-248.

Mondada, L. (2011). Understanding as an embodied, situated and sequential achievement in interaction. Journal of Pragmatics, 43(2), 542-552.

*Mori, J., \& Hasegawa, A. (2009). Doing being a foreign language learner in a classroom: Embodiment of cognitive states as social events. IRAL - International Review of Applied Linguistics in Language Teaching, 47(1), 65-94.

Najvar, P., Najvarová, V., Janík, T., \& Šebestová, S. (2011). Videostudie v pedagogickém výzkumu. Brno: Paido.

Nečesaná, J. (1972). Skupinové vyučování na nižším stupni ZDŠ jako příprava na řešení problémových úloh ve vyšších ročnících. Pedagogika, 22(3), 311-319.

Nekvapil, J. (2017). Konverzační analýza. In P. Karlík, M. Nekula, \& J. Pleskalová (Eds.), CzechEncy - Nový encyklopedický slovník češtiny. Dostupné z https: / /www.czechency.org /slovnik/KONVERZAČNÍ ANALÝZA 
*Niemi, K. (2014). “I will send badass viruses." Peer threats and the interplay of pretend frames in a classroom dispute. Journal of Pragmatics, 66(5), 106-121.

*Niemi, K., \& Bateman, A. (2015). „Cheaters and Stalkers“: Accusations in a classroom. Discourse Studies, 17(1), 83-98.

Obrovská, J. (2018). Roma identity and ritual in the classroom: The institutional embeddedness of ethnicity. Cham: Palgrave Macmillan.

*Park, I. (2014). Stepwise advice negotiation in writing center peer tutoring. Language and Education, 28(4), 362-382.

Poláček, J. (2015). Komunikační bariéry v počítačem podporovaném skupinovém učení. Pedagogika, 65(3), 314-329.

Pražská skupina školní etnografie. (2002). 8. třída. Dostupné z http://kps.pedf.cuni.cz/psse /index.php?p=8.trida

*Reichert, T., \& Liebscher, G. (2012). Positioning the expert: Word searches, expertise, and learning opportunities in peer interaction. The Modern Language Journal, 96(4), 599-609.

*Rusk, F., Sahlström, F., \& Pörn, M. (2017). Initiating and carrying out L2 instruction by asking known-answer questions: Incongruent interrogative practices in bi- and multilingual peer interaction. Linguistics and Education, 38, 55-67.

Sacks, H. (1984). Notes on methodology. In J. M. Atkinson \& J. Heritage (Eds.), Structures of social action: Studies in conversation analysis (s. 21-27). Cambridge: Cambridge University Press.

Sacks, H., Schegloff, E. A., \& Jefferson, G. (1974). A simplest systematics for the organization of turn-taking for conversation. Language, 50(4), 696-735.

*Scott, V. M. , \& Fuente, M. J. D. L. (2008). What's the problem? L2 learners' use of the L1 during consciousness-raising, form-focused tasks. The Modern Language Journal, 92(1), 100-113.

Seedhouse, P. (2004). The interactional architecture of the language classroom: A conversation analysis perspective. University of Michigan: Blackwell Publishing.

Schegloff, E. A., \& Sacks, H. (1973). Opening up closings. Semiotica, 8(4), 289-327.

Skukauskaite, A., Rangel, J., Rodriguez, L. G., \& Krohn Ramón, D. (2015). Understanding classroom discourse and interaction: Qualitative perspectives. In N. Markee (Ed.), The handbook of classroom discourse and interaction (s. 44-59). Chichester: John Wiley \& Sons.

Smetáčková, I., Novotná, H., \& Šimečková, P. (2014). Žákovská verbální vulgarita o přestávkách a o vyučování. Studia paedagogica, 19(3), 47-64.

Spolsky, B., \& Hult, F. (Ed.). (2008). The handbook of educational linguistics. Oxford: Wiley-Blackwell.

Sternberg, R. J. (2009). Kognitivní psychologie (2. vyd.; F. Koukolík, přel.). Praha: Portál.

Streeck, J., Goodwin, Ch., \& LeBaron, C. D. (Eds.). (2011). Embodied interaction: Language and body in the material world. Cambridge: Cambridge University Press.

*Sundrarajun, C., \& Kiely, R. (2010). The oral presentation as a context for learning and assessment. Innovation in Language Learning and Teaching, 4(2), 101-117.

Šed'ová, K., Švařiček, R., Sedláček, M., \& Šalamounová, Z. (2016). Jak se učitelé učí: Cestou profesního rozvoje $k$ dialogickému vyučování. Brno: MU.

Šed'ová, K., Švaříček, R., \& Šalamounová, Z. (2012). Komunikace ve školní trídě. Praha: Portál.

Št'astný, V. (2016). Klíčová témata a metody ve výzkumu soukromého doučování. Orbis scholae, 10(1), 35-62.

Tůma, F. (2016). Konverzační analýza a interakce ve tříě: Východiska a metodologické aspekty. Pedagogická orientace, 26(3), 415-441.

Tůma, F. (2017a). Interakce ve výuce anglického jazyka na vysoké škole pohledem konverzační analýzy. Brno: MU.

Tůma, F. (2017b). Střídání kódů ve výuce angličtiny u učitelů-expertů pohledem konverzační analýzy. Slovo a slovesnost, 78(4), 283-304.

*Unamuno, V. (2008). Multilingual switch in peer classroom interaction. Linguistics and Education, 19(1), 1-19. 
28 Václavík, V. (2002). Organizační formy výuky. In Z. Kalhous \& O. Obst, et al., Školní didaktika (s. 293-306). Praha: Portál.

Waring, H. Z. (2015). Theorizing pedagogical interaction: Insights from conversation analysis. New York: Routledge.

Mgr. František Tůma, Ph.D., katedra anglistiky a amerikanistiky Masarykova univerzita, Filozofická fakulta Arna Nováka 1/1, 60200 Brno tuma@phil.muni.cz

Mgr. Linda Nepivodová, Ph.D., katedra anglistiky a amerikanistiky Masarykova univerzita, Filozofická fakulta Arna Nováka 1/1, 60200 Brno lindanepi@phil.muni.cz

Nicola Fořtová, M.A., katedra anglistiky a amerikanistiky Masarykova univerzita, Filozofická fakulta Arna Nováka 1/1, 60200 Brno fortova@phil.muni.cz

\section{Příloha: Seznam použitých transkripčních značek}

(2.0)

(.)

(slovo)

slo-

-

,

?

:

<slovo>

$>$ slovo $<$

${ }^{\circ}$ slovo ${ }^{\circ}$

\$slovo\$

.h

$=$

[]

$+$

$\bullet$

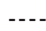

$-->$

$-->>$

$>>-$ pauza 2 sekundy

mikropauza (přibližně desetina sekundy)

špatně srozumitelné slovo

náhlé ukončení

klesavá intonace

krátký pokles nebo vzrůst intonace

stoupavá intonace

prodloužená hláska

relativně pomalejší tempo řeči

relativně rychlejší tempo řeči

relativně nižší hlasitost

pobavený tón

slyšitelný nádech

okamžité navázání replik

překrývající se slova

označuje začátek úkonů prováděných Táňou (tá)

označuje začátek úkonů prováděných Soňou (so)

popsaný úkon pokračuje

popsaný úkon pokračuje až po další značku

popsaný úkon pokračuje za konec transkriptu

popsaný úkon začal před začátkem transkriptu

označuje okamžik, ze kterého pochází přiložený obrázek 